\title{
HYBRID LEARNING TIME MODIFICATION CAN IMPROVE LEARNING ACTIVITY AND LEARNING OUTCOMES
}

\author{
Umi Kulsum
}

Surel:kulsum2406@gmail.com

\begin{abstract}
The purpose of this study was to determine the effectiveness of hybrid learning time modification in terms of learning outcomes; knowing the relationship between learning activities and learning outcomes and knowing the effect of hybrid and one other group is the conventional group (face-to-face only), this group is the control group.Collecting data using a learning activity questionnaire and a knowledge test to determine learning outcomes. Data analysis technique with Ancova. The results of the study: (1) hybrid learning time modification is effective in improving learning outcomes (2) significant relationship between learning activity and learning outcomes, significance 0.000; (3) there is a significant difference in the effect of variations in hybrid learning time modification on learning activity and learning outcomes, the significance of 0.037
\end{abstract}

Keywords: Time Modification, Hybrid Learning, Active Learning, Learning Outcomes

\section{ABSTRAK}

Tujuan penelitian ini adalah untuk mengetahui keefektifan modifikasi waktu pembelajaran hybrid ditinjau dari hasil belajar; mengetahui hubungan aktivitas belajar dengan hasil belajar serta mengetahui pengaruh modifikasi waktu pembelajaran hybrid terhadap aktivitas belajar dan hasil belajar.Desain penelitian ini adalah Non-Equivalent Control Group Design, terdiri dari empat kelompok perlakuan dengan proporsi modifikasi waktu pembelajaran hybrid dan satu kelompok lainnya adalah kelompok konvensional (tatap muka saja), kelompok ini adalah kelompok kontrol.Pengumpulan data menggunakan angket aktivitas belajar dan tes pengetahuan untuk mengetahui hasil belajar. Teknik analisis data dengan Ancova. Hasil penelitian: (1) modifikasi waktu pembelajaran hybrid efektif dalam meningkatkan hasil belajar (2) hubungan signifikan antara aktivitas belajar dengan hasil belajar, signifikansi 0,000 ; (3) terdapat perbedaan pengaruh yang signifikan variasi modifikasi waktu pembelajaran hybrid terhadap aktivitas belajar dan hasil belajar, signifikansi 0,037

Kata Kunci : Modifikasi Waktu, Hybrid Learning, Keaktifan Belajar, Hasil Belajar

\section{PENDAHULUAN}

Kemajuan teknologi informasi dan komunikasi telah memberikan pengaruh yang luar biasa terhadap pergeseran paradigma baru dalam bidang pendidikan. Bentuk teknologi informasi yang memiliki kontribusi besar dalam mengubah proses pembelajaran dalam pendidikan adalah e-learning. Salah satu perubahan yang terjadi adalah kurangnya interaksi antara guru dan 
siswa di dalam kelas karena waktu yang tersedia terbatas. Hal ini memungkinkan pembelajaran jarak jauh. Seperti dikutip dari buku yang ditulis oleh Parren, et.al.(2017) "Applications of CALL Theory in ESL and EFL Environments". Konsep pembelajaran dengan memberikan solusi gangguan terutama saat siswa tidak hadir di kelas, atau waktu tatap muka yang kurang sehingga pembelajaran di kelas menggeser pembelajaran dimana saja dan kapan saja, fasilitas fisik bergeser ke fasilitas jaringan.

Selain pemanfaatan unsur teknologi informasi secara optimal, yang diperlukan dalam pembelajaran adalah tidak meninggalkan pola bimbingan langsung guru dan pemanfaatan sumber belajar yang lebih luas. Dalam pembelajaran yang diperlukan adalah memanfaatkan unsur teknologi informasi, dengan tidak meninggalkan pola bimbingan langsung dari guru dan menggunakan sumber belajar yang lebih luas. Dampak yang begitu luas telah memberikan warna baru pada sistem pendidikan, terbukti dengan banyaknya perkembangan model pembelajaran konvensional tatap muka ke pendidikan terbuka dengan memanfaatkan teknologi informasi dan komunikasi (e-learning) sebagai media pembelajaran. Kombinasi konsep pembelajaran ini disebut dengan Hybrid Learning. Klimova, BF \& Kacetl, J. (2015) dalam artikel mereka "Pembelajaran Hibrida dan perannya saat ini dalam pengajaran bahasa asing." Penelitian ini bertujuan untuk menggali persepsi tentang konsep hybrid learning, serta mendeskripsikan metodologi seperti integrasi komponen tatap muka dan komponen instruksional secara terintegrasi secara on line.

Suatu pendekatan dari Hybrid Learning dengan menggabungkan yang terbaik yang berupaya menggabungkan manfaat terbaik dari metode pengajaran "lama" dan "baru" sehingga kualitas pembelajaran yang dikembangkan adalah kualitas optimal yang lebih baik dari sekedar kualitas tatap muka atau sekedar pembelajaran online. Menurut Syamsuddin, N., \& Kaur, J. (2020) hybrid learning adalah suatu pendekatan dalam sistem pendidikan yang menyediakan mode multidelivery untuk mengoptimalkan hasil belajar. Penelitian ini bertujuan untuk mengetahui gaya belajar siswa dan hubungannya dengan persepsi pembelajaran hybrid. Gaya belajar siswa ditentukan menggunakan Kolb's Learning Style Inventory, dan persepsi siswa terhadap pembelajaran hybrid dinilai menggunakan one-way ANOVA untuk mengetahui korelasinya dengan gaya belajar siswa. Hasil penelitian menunjukkan bahwa tidak terdapat perbedaan yang signifikan antara gaya belajar siswa dan persepsi terhadap hybridsedang belajar. Temuan ini diyakini dapat meningkatkan prestasi siswa.

Dalam proses pembelajaran, aktivitas siswa sangat diperlukan untuk menciptakan suasana kelas yang bermakna dan pembelajaran yang optimal. Kegiatan belajar siswa 
yang relevan dalam pembelajaran adalah yang dapat mengubah perilaku siswa sesuai dengan tujuan pembelajaran.

\section{METODE PENELITIAN}

Desain dalam penelitian ini adalah Non-Equivalent Control Group Design. Desain ini memiliki kelompok kontrol, tetapi tidak sepenuhnya berfungsi untuk mengontrol variabel eksternal yang mempengaruhi pelaksanaan eksperimen. Kelompok eksperimen dan kelompok kontrol dipilih dengan pertimbangan terbaik dari karakteristik masing-masing kelompok.

Penelitian dibagi menjadi 4 (empat) kelompok perlakuan dengan proporsi waktu pembelajaran hybrid yang bervariasi, masing-masing 2 jam pelajaran (artinya 2x45 menit pembelajaran hybrid dan $3 \times 45$ menit tatap muka); 3 jam pelajaran (artinya $3 \times 45$ menit pembelajaran hybrid dan 2x45 menit tatap muka); dan 4 jam pelajaran (artinya 4x45 menit pembelajaran hybrid dan 1x45 menit tatap muka). Satu kelompok lainnya adalah kelompok konvensional, yaitu kelompok kontrol. Sampel dalam penelitian ini adalah siswa kelas XI program keahlian Tata Busana yang berjumlah 104 siswa.

Pengumpulan data dilakukan dengan tes pengetahuan dan angket. Teknik Analisis Data Ancova (Analisis Kovarians)

\section{HASIL PENELITIAN DAN PEMBAHASAN}

Setelah dilakukan analisis data untuk pengujian hipotesis, maka dilakukanlah hasil analisis data. Hasil analisis data dapat dilihat pada tabel berikut.

Tabel 1. Hasil Analisis Rata-Rata Hasil Belajar Kelompok Eksperimen (Kelompok 1,2,3) Dan Kelompok Kontrol (Kelompok 4)

\begin{tabular}{lllll} 
Dependent Variable: & Learning Outcomes & & & \\
\hline Treatment & $\begin{array}{c}\text { Proportion of } \\
\text { hybrid learningin } \\
\text { time modification } \\
\text { (hours) }\end{array}$ & Mean & $\begin{array}{c}\text { Std. } \\
\text { Deviation }\end{array}$ & N \\
\hline 1 & 4 & 73,46 & 8,575 & 26 \\
2 & 3 & 77,12 & 6,953 & 26 \\
3 & 2 & 69,81 & 9,108 & 26 \\
4 (control) & 0 & 53,65 & 9,006 & 26 \\
Total & & 68,51 & 12,265 & 104 \\
\hline
\end{tabular}


Tabel 2. Hasil Uji Analisis Kovarians Aktivitas Belajar dengan Hasil Belajar

Variabel Dependen: Hasil Belajar

\begin{tabular}{|c|c|c|c|c|c|c|c|c|}
\hline Source & $\begin{array}{c}\text { Type III } \\
\text { Sum of } \\
\text { Squares }\end{array}$ & df & $\begin{array}{c}\text { Mean } \\
\text { Square }\end{array}$ & $\mathbf{F}$ & Sig. & $\begin{array}{l}\text { Partial } \\
\text { Eta } \\
\text { Squa } \\
\text { red }\end{array}$ & $\begin{array}{l}\text { Non } \\
\text { cent. } \\
\text { Para } \\
\text { meter }\end{array}$ & $\begin{array}{l}\text { Obser } \\
\text { ved } \\
\text { Powerb }\end{array}$ \\
\hline Corrected & $10575,025^{\mathrm{a}}$ & 5 & 2115,005 & 42,137 & ,000 & ,683 & 210,685 & 1,000 \\
\hline \multicolumn{9}{|l|}{ Model } \\
\hline Intercept & 29,540 & 1 & 29,540 & ,589 & , 445 & ,006 & ,589 & , 118 \\
\hline $\begin{array}{l}\text { Self- } \\
\text { reliance }\end{array}$ & 746,120 & 1 & 746,120 & 14,865 & ,000 & , 132 & 14,865 & ,968 \\
\hline Liveliness & 406,359 & 1 & 406,359 & 8,096 & ,005 & ,076 & 8,096 & ,804 \\
\hline Treatment & 440,901 & 3 & 146,967 & 2,928 & ,037 & ,082 & 8,784 & ,680 \\
\hline Error & 4918,965 & 98 & 50,194 & & & & & \\
\hline Total & 503625,000 & 104 & & & & & & \\
\hline Corrected & 15493,990 & 103 & & & & & & \\
\hline Total & & & & & & & & \\
\hline
\end{tabular}

Pembahasan

Hasil penelitian juga menunjukkan adanya hubungan yang signifikan antara aktivitas belajar dengan hasil belajar. Nilai signifikansi aktivitas belajar adalah 0,000 ,artinya nilai tersebut lebih kecil (<) dari signifikansi 0,05. Selain itu, terdapat perbedaan yang signifikan antara hybrid learning dan hasil belajar dengan signifikansi 0,037, artinya nilai tersebut lebih kecil $(<)$ dari taraf signifikansi 0,05. Dari hasil tes yang dilakukan pada semua kelompok perlakuan dan kelompok kontrol, rata-rata hasil tertinggi dari hasil penelitian berada pada kelompok perlakuan kedua dengan proporsi waktu pembelajaran hybrid (3x45 menit). Hasil penelitian ini sesuai dengan Proporsi Comprehended online (proporsi konten yang disampaikan secara online) yang ditulis oleh Allen, dkk. (dalam Nurmahen, 2017). Mereka menyediakan kategori yang jelas untuk Pembelajaran Hibrid, pembelajaran tradisional, peningkatan web, dan pembelajaran online. Pembelajaran dikatakan dalam bentuk Hybrid apabila porsi e-learning berada pada kisaran $30-79 \%$, dalam hal ini modifikasi waktu pembelajaran berada pada proporsinya $(3 \%$ online $=5$ kelas atau 15 jam) atau 3 jam per kelas, artinya ( $3 \times 45$ menit) digabung dengan pembelajaran tatap muka. Laporan; Konsorsium Sloan Mengenai modifikasi waktu belajar, mengutip hasil penelitian yang dilakukan oleh Hamdi \& Slamet, S. (2016) bahwa penerapan modifikasi pembelajaran dan umpan balik sederhana dapat memberikan hasil yang signifikan terhadap waktu pembelajaran aktif dalam melakukan gerakan-gerakan permainan bola voli pada siswa kelas X SMA Kartika XIX-2 Bandung. Selanjutnya hasil penelitian Imanuel, D. (2017) menemukan bahwa pembelajaran motivasional valid dan 
reliabel dengan nilai 0,775 dan 0,795 , maka dapat disimpulkan bahwa model motivasi dengan menggunakan jam efektif siswa sebagai moderator dapat meningkatkan hasil belajar siswa di sekolah. Penelitian yang sama juga dilakukan oleh Hasan, M.S., \& Sari, K.T. (2021). Penelitian ini bertujuan untuk mengetahui pengaruh manajemen waktu terhadap hasil belajar siswa pada mata pelajaran fiqh di Madrasah Tsanawiyah Al-As'Ad Brambang Diwek Jombang. Hasil penelitian menunjukkan (1) pengelolaan waktu siswa dinyatakan baik dengan persentase 43,33\%, (2) hasil belajar siswa dinyatakan cukup baik dengan persentase $60 \%$, (3) terdapat signifikansi pengaruh antara manajemen waktu terhadap hasil belajar siswa pada mata pelajaran fiqh. dengan nilai 0,019 lebih kecil dari nilai probabilitas 0,05

Di sisi lain, model Hybrid Learning mendorong guru untuk mengubah paradigma pendidikan dari pembelajaran yang berpusat pada guru menjadi pembelajaran yang berpusat pada siswa. Seperti yang diungkapkan oleh Mohamad, Masek, Zamawi, \& Mohd. Zuki (2020) menyiratkan bahwa pelaksanaan kegiatan pembelajaran yang berpusat pada siswa dapat dirancang untuk menekankan faktor sikap dan motivasi, tanpa mempertimbangkan faktor gender untuk mencapai partisipasi aktif dan pembelajaran yang efektif dan tingkat partisipasi dalam kegiatan pembelajaran yang berpusat pada siswa. Sementara itu, penelitian Hariadi, B., dkk. (2019) dengan menggunakan brilian, adalah aplikasi pembelajaran hybrid yang menggabungkan pembelajaran tatap muka dan pembelajaran online. Penelitian ini merupakan penelitian pra-eksperimen dengan rancangan one group pre-test and post-tset design. Data yang terkumpul dianalisis menggunakan uji Wilcoxon dan uji Mann-Whitney U. Hasil penelitian menunjukkan bahwa pembelajaran hybrid sangat efektif untuk meningkatkan hasil belajar siswa, yang ditunjukkan oleh: (1) peningkatan hasil belajar siswa adalah signifikan secara statistik pada 5\%; (2) mean n-gain dalam kategori tinggi; (3) mean n-gain tidak berbeda antara kedua kelompok siswa.

\section{SIMPULAN}

Berdasarkan pembahasan di atas, dapat disimpulkan bahwa hasil penelitian adalah sebagai berikut: (1) modifikasi waktu pembelajaran hybrid learning dapat meningkatkan aktivitas belajar dan hasil belajar; (2) terdapat peningkatan nilai rata-rata hasil belajar pada kelompok perlakuan dibandingkan pada kelompok kontrol; (3) terdapat hubungan yang signifikan antara aktivitas belajar dengan hasil belajar; (4) terdapat perbedaan pengaruh yang signifikan variasi modifikasi pembelajaran hybrid terhadap aktivitas belajar dan hasil belajar; (5) pembelajaran melalui pembelajaran hybrid dengan modifikasi waktu belajar direkomendasikan sebagai model trend pembelajaran yang 
paling efektif dalam mengoptimalkan proses pembelajaran

\section{DAFTAR RUJUKAN}

Adi, S. 2014. Pengaruh Modifikasi Waktu Belajar Terhadap Peningkatan Kebugaran, Konsep Diri, dan Prestasi Akademik. Surabaya: Disertasi, tidak Dipublikasikan.

Dewantara, D., Wati, M., Misbah, Mahtari, S., Haryandi, S. 2020. Blended Learning to Improve Learning Outcomes in Digital Electronics Courses. https://doi.org/10.2991/assehr.k.20 0219.054

Hamdi \& Slamet, S. 2016. Implementasi Modifikasi Pembelajaran dan Simple Feedback Dalam Pembelajaran Aktivitas Permainan Bola Voli Untuk Meningkatkan Waktu Aktif Belajar. Jurnal Pendidikan Jasmani dan Olahraga, Vol.1 No.2, September 2016.

Hariadi, B., Sunarto, M.J.D., Sudarmaningtyas, P., Jatmiko, B. 2019. Hybrid learning by using brilian applications as one of the learning alternatives to improve learning outcomes in college. International Journal of Emerging technologies in Learning 14(10), pp.34-45

Klimova, B.F., Kacetl, J. 2015. Hybrid Learning and its Current Role in the Teaching of Foreign languages. Procedia-Social and Behavioral Science 182, page 477 -481, Published by Elsevier Ltd.
Mizokami S. 2018. Deep Active Learning from the Perspective of Active Learning Theory In: Matsushita K. (eds) Deep Active Learning. Springer, Singapore. https://doi.org/10.1007/978-98110-5660-4_5

Mohamad, N., Masek, A., Zawawi, Z., \& Mohd Zuki, F. S. 2020. Attitude and Motivation of Engineering Students' towards Participating in Student-Centered Learning Activities. Universal

Nurmahen. 2017. Pengaruh Metode Blended Learning Terhadap Pemahaman Konsep Dalam Pembelajaran IPS. (Universitas Pendidikan Indonesiarespository.upi.edu)

Sudjana, Nana. 2016. Penilaian Hasil Proses Belajar Mengajar. Bandung: Remaja Roesdakarya 